\title{
Credit Hour to Contact Hour: Using the Carnegie Unit to Measure Student Learning in the United States
}

\author{
Amy McMillan \\ East Carolina University \\ Dennis Barber III \\ East Carolina University
}

The credit hour unit of measurement in academia was created over 100 years ago to measure teacher productivity. Despite a recent review by the Carnegie Foundation, the definition remains unchanged. Federal guidelines have used the Carnegie unit to determine federal funding of universities. As such, the credit hour is a critical part of accreditation. In this paper, we examine definitions of the credit hour as contact hours and explore university interpretations used in policy making. We call for faculty to investigate how their universities and accrediting bodies are defining student learning based on the credit hour to contact hour definition.

Keywords: credit hour, contact hour, student learning outcomes, accreditation, carnegie unit, experiential learning

\section{INTRODUCTION}

For over 100 years the credit hour has been used as a measure of teacher productivity and student learning. It was initially created only to measure one of those, teacher productivity. Given that pedagogy has changed, and there are many ways to learn and assess learning, we argue that the credit hour to contact hour guidelines are no longer effective as a measure of student learning. We have a more thorough understanding of how to measure student learning using the assessment of objectives. Course, program and degree-level assessment have progress substantially since the early to mid-1900s. However, universities and academic committees often take the easy way out when setting credit hour guidelines. It is simpler to measure contact hours than it is to develop broad program objectives across the university. As such, we find that the guidelines are getting more and more specific instead of broad enough to encompass various pedagogical approaches.

In this paper, we will first define the credit hour as determined by both the Carnegie unit and federal guidelines. We consider how accrediting bodies, such as the Southern Association of Colleges and Schools Commission on Colleges (SACSCOC), approach credit hours in their review and how as a result, universities ultimately define, and measure, credit hours as contact hours. Then we offer a discussion of various pedagogies such as experiential learning and service-learning that defy the credit hour and contact hour guidelines. Finally, we will present suggestions for broadening the definition and future research in this area. It should be noted that this review, while it considered definitions of credit hours from a broad, 
university perspective, we then narrowed it down to regional accrediting bodies and then discipline specific (AACSB).

\section{BACKGROUND}

\section{The Credit Hour}

What started in 1906 to determine pension eligibility for faculty very quickly became a measure of rigor and student learning in the classroom. The Carnegie Foundation determined that faculty workload could be measured in terms of credit hours for courses taught. This credit hour was then used to pay out pensions to faculty that might not have otherwise been able to retire. While faculty pensions have changed drastically over the last 100 years, including the adoption of $401 \mathrm{ks}$, the credit hour has remained and even transformed into a measure of student learning. It is defined as one hour of classroom instruction with 2 hours of external preparation or studying for each one credit hour, typically spread over a 15-16 week course (Silva, White, \& Toch, 2015). The understanding is that when courses are condensed into a quarter system or 5-week summer session the credit hour to contact hour ratio remains the same. Whether it is 15 weeks or 5 weeks the expectation is still 45 hours of contact time with the instructor and 90 hours of prep time (Silva, White, \& Toch, 2015).

\section{Federal Regulations}

As stated previously, this measure of credit hours has gone far beyond determining faculty workloads. It is now the standard measure of student learning. The federal government joined the credit hour bandwagon as it relates to financial aid and funding. In fact, n CFR 34 600.2 (See Appendix Exhibit A) (Institutional Eligibility Under the Higher Education Act of 1965, As Amended, 2019) defines a credit hour

as an amount of work represented in intended learning outcomes and verified by evidence of student achievement that is an institutionally established equivalency that reasonably approximates not less than one hour of classroom or direct faculty instruction and a minimum of two hours of out of class student work each week for approximately fifteen weeks for one semester or trimester hour of credit, or ten to twelve weeks for one quarter hour of credit, or the equivalent amount of work over a different amount of time.

There is some leeway for accrediting bodies, and there is even mention of correspondence courses and telecommunications (i.e. distance education) in the guidelines. There is, although, not much guidance in terms of what these hours of instruction may look like. Most institutions interpret it to be time inside the classroom or watching video lectures. The Carnegie Unit, adopted by the federal government, is the standard that has been adopted by most accrediting agencies and universities in their endeavor to maintain or increase federal funding dollars.

\section{Accrediting Agencies}

The accrediting agency SACSCOC asserts in the 2018 Principles of Accreditation it will review participating universities' guidelines on credit hours (Southern Association of Colleges and Schools Commission, 2017). They go on to state that the guidelines should be in accordance with federal regulations and the Carnegie unit. In a somewhat contradictory statement, the Principles of Accreditation assert that the guidelines do not indicate a specific amount of time in the classroom and out of the classroom. They then also declare that to the extent an institution believes that complying with the federal definition of a credit hour would not be appropriate for academic and other institutional needs, it may adopt a separate measure for those purposes. There are no guidelines or suggestions for how this might be accomplished.

The Association to Advance Collegiate Schools of Business (AACSB) uses the credit hour as a measure of faculty teaching load. In a review of the accreditation standards, there was no mention of the 
credit-hour to contact-hour as a measure of student learning. This is in line with the original intention of the Carnegie Unit, as a measure of faculty teaching load. Instead, AACSB focuses on assurances of learning and the assessment of student learning outcomes in terms of objectives. For example, the 2013 AACSB accreditation standards identify several attributes expected of accredited business programs, namely that their curricula

"facilitate and encourage active student engagement in learning. In addition to time on task related to readings, course participation, knowledge development, projects, and assignments, students engage in experiential and active learning designed to be inclusive for diverse students, and to improve skills and the application of knowledge in practice" (AACSB, 2013).

It becomes clear that the guidelines provided by SACSCOC provide universities with the easiest path possible to creating credit hour policies. The message is "stick to the Carnegie unit and Federal regulations and everything will be fine". This assertion was strengthened when a few years ago the Carnegie Foundation re-examined the Carnegie unit for credit hours and determined that it was still the best way to gauge rigor and student learning. There is however a misalignment between what the university level accrediting agency uses as a measure of student learning and what the more discipline specific level accrediting agency uses as a measure of student learning. AACSB has it right, in measuring student learning according to learning outcomes, while SACSCOC emphasizes the use of hours in a seat or hours in contact with the material. There are many modern pedagogical approaches to facilitating learning. A lecture style approach is not the only way to encourage learning and may be one of the least effective in certain fields. The standards sent down from SACSCOC are forcing universities to develop specific guidelines and policies that are tied to these very measures.

\section{University Definitions}

By and large, nearly every examined institution uses the federal definition outlined in 34 CFR $\S 600.2$ as the basis for their credit hour definition. Many schools, such as the University of AlabamaBirmingham and East Carolina University, simply use a carbon copy of this definition (See Appendix Exhibit B). Others, such as Alabama State and Brown, use similar definitions that follow the same spirit of the federal definition but do not use the exact language. Almost every school maintains the federal definition's ratio of 2 hours of out-of-class work for every 1 hour of in-class instruction. Nearly every school also uses the "Carnegie unit" when defining hours, resulting in one-hour being represented by a 50-minute instructional period. Schools that do stray from the federal definition typically do so in a manner that results in policy becoming stricter, rather than more lenient. This is observed in North Carolina Central University's definition, which requires 3 hours of out-of-class work for every 1 hour of instruction, as opposed to the normal 2:1 ratio. The one outlier in the examined institutions is the University of South Carolina. They simply define a credit hour as "50 minutes per week over the entire term" and make no reference to the ratio of work used in every other institution's definition. This could be due to them basing their definition on that used by Integrated Postsecondary Education Data System (IPEDS), the US Department of Education's higher education statistics and research arm, as opposed to the federal regulatory definition adopted by other organizations.

Universities have moved beyond a definition of credit hour based on federal guidelines, and, in order to satisfy accreditation standards, have begun to adopt policies and guidelines that identify the number of hours total required for each type of instructional format (See Appendix Exhibit C). Guidelines go as far as to identify the number of contact hours for one credit hour of lecture, lecture + lab, practicum, physical activity, and so forth. For example, in the guidelines we found that 1 credit hour of practicum resulted in 45 hours contact hours per semester or as required by an accrediting body. Of the 16 schools and system guidelines that we examined, 9 included specific contact hours in their definition of credit hours. The trend is moving towards more explicit guidelines instead of broader guidelines. 
If most universities are adopting this approach and the Carnegie Foundation is unwilling to consider changes to the credit hour guidelines and the federal regulations depend upon that unit, then how are universities supposed to come up with their own policy that encompasses modern forms of pedagogy? For example, experiential learning often takes place outside of the classroom, even in face to face classes. This interaction would often not be logged as contact hours with the instructor because students are in contact with clients, customers, etc. Additionally, there are many ways to assess student learning besides formal in-class exams at the end of the semester. In fact, universities are creating policies requiring faculty to be in class during set final exam times because they are part of the total number of hours required for credit hour to contact hour definitions (See Appendix, Exhibit D). Some interpretations even suggest that if a faculty member does not have an in-class exam the faculty member must still be sitting in the classroom with no students, just to meet what is interpreted to be the university and federal guidelines for accreditation purposes. If there is no contact with the students, then how can this be considered in the overall measurement of contact hours? These are very narrow interpretations that are inefficient, unnecessary and irrelevant with respect to student learning outcomes.

\section{Experiential Learning}

Experiential learning has become an increasingly popular method in higher learning education (Austin \& Rust, 2015). Multiple definitions of this learning have been presented over the decades, with one of the oldest being found in Dewey's work Accredited Experiential Education: Some definitions (1971). Dewey describes experiential learning as a process in which the student learns by doing (1971). Kolb \& Kolb (2005) expand on this definition and posit several propositions of experiential learning theory. Namely:

1. Learning is best conceived as a process, not in terms of outcomes.

2. All learning is relearning.

3. Learning requires the resolution of conflicts between dialectically opposed modes of adaptation to the world.

4. Learning is a holistic process of adaptation to the world.

5. Learning results from synergetic transactions between the person and the environment.

6. Learning is a process of creating knowledge.

Kolb \& Kolb based this analysis on the work of Dewey, and both emphasized the importance of reflection when examining the efficacy of experiential learning (Dewey, 1971; Kolb \& Kolb, 2005). Higgins (2009) expands on this, espousing the importance of critical reflection when instituting an experiential learning model.

The efficacy of experiential learning in the classroom has been examined in various fashions. Kuh (2008) showed that experiential learning practices are high-impact practices that increase student engagement and retention. Other researchers have presented experiential education curricula as some of the most powerful teaching tools available (McCarthy \& McCarthy, 2006; Winsett, Foster, Dearing, \& Bursch, 2016). In the scope of experiential learning, internship/cooperative programs have become common in university settings (Austin \& Rust, 2015). Internship programs help students learn whether they are suited for a particular career and have been linked to greater job satisfaction later in life (Steffes, 2004). Purdie, Ward, McAdie, King, and Drysdale (2013) surveyed 716 UK undergraduate students that participated in work-learning programs. These students reported significantly greater confidence in goal setting and goal attainment.

Experiential learning curriculums have been used in higher education business programs (Elam \& Spotts, 2004; Marom \& Lussier, 2017) as well as specifically entrepreneurship programs (Neck \& Greene, 2010). When examining MBA programs, Ryan, Silvanto, \& Brown (2013) showed those that emphasized experience-based learning in the form of international travel tended to have more internationally mobile graduates. Given the growing importance of this curricula in business programs, accreditation agencies have started to emphasize them. 
Experiential education has typically taken the form of internships in a business program. Researchers, however, have presented alternatives that may better fulfill the AACSB standards. Kosnik, Tingle, \& Blanton (2013) posited that experiential learning projects could better represent the AACSB's values of innovation, impact, and engagement. While internships are more individual in nature and focus on the day-to-day operations of an employer, experiential learning projects would run more concurrently with the applicable coursework and provide more opportunities for the student to work in a team environment. However, it was also noted that these projects would rely heavily on faculty guidance and would limit students' exposure to client organizations (Kosnik, Tingle, \& Blanton, 2013).

\section{Service Learning}

Service learning is a particular form of experiential learning, which focuses on the student interacting with local agencies and affecting change within the community (Levesque-Bristol, Knapp, \& Fisher, 2011). Cashman \& Seifer (2008) describes service learning as a learning environment which is structured and focuses on community interaction where preparation and reflection of the students is crucial. On differentiating between experiential learning and service learning, Furco (1996) states that service learning is distinguished by its intention to benefit the service provide as well as the entity or persons receiving the service. In essence: while an internship is predominantly beneficial to the student, a servicelearning curriculum compels the student to benefit their community and allows the service to co-occur with the student's learning (Cashman \& Seifer, 2008). In defining the concept, Seifer (1998), offered several elements of service learning, stating that service learning:

- Has its theoretical roots in experiential learning theory;

- Is developed, implemented, and evaluated in collaboration with the community;

- Responds to community-identified concerns;

- Attempts to balance the service that is provided and the learning that takes place;

- Enhances the curriculum by extending learning beyond the lecture hall and allowing students to apply what they are learning to real-world situations; and

- Provides opportunities for critical reflection.

Implementing service learning programs has been shown to positively influence students' personal development, leadership, and communication skills; racial and cultural understanding; sense of social and civic responsibility; course content learning and ability to apply classroom learning in real-world situations (Eyler, Giles, Stenson, \& Gray, 2001). Astin, Vogelgesang, Ikeda, \& Yee (2000) examined the longitudinal effects of service-learning participation in undergraduates, and found significant positive effects in all measured outcomes: academic performance, values, self-efficacy, leadership, choice of service career, and plans to participate in service after college.

With the increased use of experiential learning/service-learning faculty are spending less time using traditional methods of pedagogy such as lecturing, standing in front of students, and more time facilitating learning in other ways. Student learning is taking place outside of the classroom. This has a direct impact on the credit hour as contact hours definition as a measure of student learning. While students may be spending more time preparing, reflecting, and directly involved with the topics they are learning, they are spending less time in front of faculty. Mentoring, facilitating, and guiding can take place in a variety of fashions which do not involve traditional methods of teaching and communicating. We are not suggesting that faculty are replaceable. In fact, it is the exact opposite. We are instead offering that faculty often spend more time designing activities that help students apply what they have learned outside the classroom rather than standing at the podium lecturing or recording videos of their lectures. These activities make it much more difficult to define contact hours as credit hours

\section{DISCUSSION}

There is a disconnect between the university level accrediting bodies' use of a credit/contact hour and the use by discipline specific accrediting bodies. The original intent of the credit and contact hour was to 
measure faculty teaching load, and discipline specific accreditors such as AACSB are using it to measure just that. It informs what a full-time, adjunct and part-time teaching load looks like. Unfortunately, the federal guidelines and university level accrediting bodies have transferred the credit and contact hour into a measure of student learning.

The credit hour is a vain metric of student learning. AACSB uses learning objectives and assessment to measure and direct student outcomes. With the recent indirect pressure towards a more experiential and engaged approach to the classroom (flipped classrooms, internships, service-learning, etc.), faculty are being asked to measure learning and engagement in conflicting manners. If faculty are encouraged to develop experiential opportunities for students outside of the classroom, then that will reduce the face-toface contact hours between faculty and students. But many universities and units still force faculty to have a certain number of contact hours with the students. This disconnect creates a disincentive for faculty, especially early in their career, to venture into experiential and engaged type of learning opportunities for students that would happen outside of the classroom. Therefore, faculty would be risking disciplinary actions from unit administrators if they fail to meet the contact hours even if this lack of contact would help students better meet the learning objectives in the course. In addition, this does not even cover the inefficiency of forcing faculty to sit in an empty room for 3 hours during a final exam time simply because it meets the contact hour requirements for the university.

Additionally, the idea of contact hours has little to do with learning. Modern pedagogy includes various methods of learning that encourage non-lecture formats. In a lecture format, faculty would stand in front of students with a PowerPoint presentation for 3 hours a week. Students learn in a variety of ways and much of that learning occurs outside the classroom. Even traditional methods of testing are less useful today than they were 10 years ago. As such, we are advocating for change, not only in how accrediting bodies like SACSCOC address credit hours but in how universities interpret the rules and guidelines. University committees need to do the real work to change the way they are using the credit hour as a measure of student learning. Instead, leave the credit hour as a measure of faculty workload and find new ways to measure student learning. In addition, accrediting bodies need to get on the same page when it comes to measures such as the credit hour. A good place to begin is the Carnegie Unit and federal guidelines.

Research on the issue of credit hour to contact hour is sparse and more is needed. For example, a wider comparison of other regional accrediting bodies as well as discipline specific accreditors is needed. We call on other disciplines to examine how their accrediting organizations define and use the credit hour. In addition, an examination of other regional university accrediting bodies needs to be conducted. There are at least seven accrediting agencies in the United States. We only examined one, SACSCOC. Further research on how other universities are interpreting these guidelines is also needed. We looked at 16 universities across the United States, but this is a small sample size. Are there differences in how public and private universities define a credit hour and apply that definition? Are there differences in how online universities approach the definition of a credit hour? Finally, more research is needed regarding how modern pedagogy impacts contact hours. We know that learning takes place outside of the classroom. We know that learning takes place in many different forms. So, how does that translate to contact hours? 


\section{REFERENCES}

AACSB. (2013). Eligibility Procedures and Accredidation Standards for Business Accredidation. Tampa FL: The Association to Advance Collegiate Schools of Business.

Astin, A., Vogelgesang, L., Ikeda, E., \& Yee, J. (2000). How Service Learning Affects Students. Higher Education, 144.

Austin, M., \& Rust, D. (2015). Developing an Experiential Learning Program: Milestones and Challenges. International Journal of Teaching and Learning in Higher Education, 27(1), 143153.

Cantor, J. (1995). Experiential learning in higher education: Linking classroom and community. Washington DC: ASHE-ERIC Higher Education Report No. 7.

Cashman, S., \& Seifer, S. D. (2008). Service-Learning: An Integral Part of Undergraduate Public Health. American Journal of Preventative Medicine, 35(3), 273-278.

Dewey, R. (1971). Accredited experiential education: Some definitions. The Urban and Social Change Review, 5(1), 10-15.

Elam, E., \& Spotts, H. (2004). Achieving Marketing Curriculum Integration: A Live Case Study Approach. Journal of Marketing Education, 26(1), 50-65.

Eyler, J., Giles, D., Stenson, C., \& Gray, C. (2001). At a glance: what we know about the effects of service-learning on college students, faculty, institutions and communities, 1993-2000: Third edition. Higher Education, 139.

Furco, A. (1996). Service-learning: a balance approach to experiential education. In B. Taylor (Ed.), Expanding boundaries: serving and learning. Washington DC: Corporation for National Service.

Higgins, P. (2009). Into the big wide world: Sustainable experiential education for the 21 st century. Journal of Experiential Education, 32(1), 44-60.

Institutional Eligibility Under the HIgher Education Act of 1965, As Amended. (2019). n 34 CFR 600.2.

Kolb, A., \& Kolb, D. (2005). Learning styles and learning spaces: Enhancing experiential learning in higher education. Academy of Management Learning \& Education, 4(2), 193-212.

Kosnik, R., Tingle, J., \& Blanton, E. (2013). Transformational learning in business education: The Pivotal Role of Experiential Learning Projects. American Journal of Business Education, 6(6), 613-630.

Kuh, G. (2008). High educational impact practices: What they are, who has access to them and why they matter? Washington DC: AAC\&U.

Levesque-Bristol, C., Knapp, T., \& Fisher, B. (2011). The Effectiveness of Service-Learning: It's Not Always What You Think. Journal of Experiential Education, 33(3), 208-224.

Marom, S., \& Lussier, R. (2017). Developing a Small Business Management Concentration within a Business Degree. Small Business Institute Journal, 13(2), 15-30.

McCarthy, P., \& McCarthy, H. (2006). When case studies are not enough: Integrating experiential learning into business curricula. Journal of Education for Business, 81(4), 201-204.

Neck, H., \& Greene, P. (2010). Entrepreneurship Education: Known Worlds and New Frontiers. Journal of Small Business Management, 49(1), 55-70.

Purdie, F., Ward, L., McAdie, T., King, N., \& Drysdale, M. (2013). Are work-integrated learning (WIL) students better equipped psychologically for work post-graduation than their non work-integrated learning peers? Some initial findings from a UK university. Asia Pacific Journal of Cooperative Education, 14(2), 117-125.

Ryan, J., Silvanto, S., \& Brown, H. (2013). The impact of experience-based MBA educational programs on international career mobility. Journal of Global Mobility, 1(1), 28-45.

Seifer, S. (1998). Service-Learning: Community-Campus Partnerships for Health Professions Education. Academic Medicine, 73(3), 273-277.

Silva, E., White, T., \& Toch, T. (2015). The Carnegie Unit: A Century Old Standard in a Changing Education Landscape. Stanford: Carnegie Foundation for the Advancement of Teaching.

Southern Association of Colleges and Schools Commission. (2017). 2018 Edition of the Principles of Accreditation. Decatur.

94 Journal of Higher Education Theory and Practice Vol. 20(2) 2020 
Steffes, J. (2004). Creating powerful learning environments beyond the classroom. Change: The Magazine of Higher Learning, 36(3), 46-50.

Winsett, C., Foster, C., Dearing, J., \& Bursch, G. (2016). The impact of group experiential learning on student engagement. Academy of Business Research Journal, 3, 20-21. 


\section{APPENDIX}

\section{Exhibit A: Federal Credit Hour Definition}

$n$ CFR 34600.2 - Credit hour: Except as provided in 34 CFR 668.8(k) and (1), a credit hour is an amount of work represented in intended learning outcomes and verified by evidence of student achievement that is an institutionally established equivalency that reasonably approximates not less than-

(1) One hour of classroom or direct faculty instruction and a minimum of two hours of out of class student work each week for approximately fifteen weeks for one semester or trimester hour of credit, or ten to twelve weeks for one quarter hour of credit, or the equivalent amount of work over a different amount of time; or

(2) At least an equivalent amount of work as required in paragraph (1) of this definition for other academic activities as established by the institution including laboratory work, internships, practica, studio work, and other academic work leading to the award of credit hours.

\section{Exhibit B: Various Definitions of Credit Hour by University}

\begin{tabular}{|c|c|c|}
\hline University/System & $\begin{array}{l}\text { Same as } \\
\text { Federal }\end{array}$ & Example (if different from federal) \\
\hline Alabama State & No & $\begin{array}{l}\text { "Approximates ACHE (Alabama Commission of Higher Education) and } \\
\text { SACSCOC (Southern Association on Colleges and Schools Commission } \\
\text { on Colleges) definitions of credit hour" }\end{array}$ \\
\hline Brown & No & $\begin{array}{l}\text { One semester credit hour is defined as a weekly minimum of } 1 \text { hour in } \\
\text { class (or other required educational meetings like labs, studios, etc.) plus } 2 \\
\text { hours of out-of-class work. Formally, therefore, a 4-credit course should } \\
\text { require } 4 \text { classroom hours and } 8 \text { hours of out-of-class hours each week in a } \\
\text { fifteen-week term. Deficiency in class time can be made up for by } \\
\text { additional out of class time on a } 2: 1 \text { basis (i.e., a } 4 \text {-credit class meeting for } \\
3 \text { hours per week should carry a minimum expectation of } 10 \text { hours of out- } \\
\text { of-class work). The total of in-class hours and out-of-class work for a } 4- \\
\text { credit course should be approximately } 180 \text { hours. }\end{array}$ \\
\hline ECU & Yes & N/A \\
\hline Iowa & Yes & N/A \\
\hline NC Central & No & $\begin{array}{l}\text { "a minimum of } 750 \text { scheduled minutes of instructional time or the } \\
\text { equivalent per credit hour over a minimum of } 75 \text { class days per semester" }\end{array}$ \\
\hline NC State & Yes & N/A \\
\hline $\begin{array}{l}\text { Ohio Department of } \\
\text { Higher Education }\end{array}$ & No & $\begin{array}{l}\text { "One semester credit hour will be awarded for a minimum of } 750 \text { minutes } \\
\text { of formalized instruction that typically requires students to work at out-of- } \\
\text { class assignments an average of twice the amount of time as the amount of } \\
\text { formalized instruction ( } 1,500 \text { minutes)." }\end{array}$ \\
\hline Oregon State & No & $\begin{array}{l}\text { One quarter credit is assigned in the following ratio of component hours } \\
\text { per week devoted to the course of study: (1) lecture \{and seminar\} } \\
\text { courses-one contact hour for each credit (two hours of outside work } \\
\text { implied); (2) laboratory, recitation, or studio courses--at least two contact } \\
\text { hours for each credit (one hour of outside preparation implied); (3) } \\
\text { independent study - at least three hours of work per week for each credit." }\end{array}$ \\
\hline Purdue & No & $\begin{array}{l}\text { Normally, one credit hour is associated with a class meeting for } 50 \\
\text { minutes per week for an entire semester (or the equivalent } 750 \text { semester- } \\
\text { minutes, excluding final exams). Another widely repeated standard states } \\
\text { that each in-class hour of college work should require two hours of } \\
\text { preparation or other outside work. }\end{array}$ \\
\hline Samford & No & $\begin{array}{l}\text { A unit of credit equates to three hours of student work per week ( } 1 \text { hour } \\
\text { in-class or direct instruction plus a minimum of } 2 \text { hours of out-of-class). }\end{array}$ \\
\hline
\end{tabular}




\begin{tabular}{|l|l|l|}
\hline South Carolina & No & $\begin{array}{l}\text { "a unit of measure representing the equivalent of an hour (50 minutes) of } \\
\text { instruction per week over the entire term." }\end{array}$ \\
\hline Texas Tech & Yes & N/A \\
\hline UAB & Yes & N/A \\
\hline $\begin{array}{l}\text { University of } \\
\text { Kentucky }\end{array}$ & Yes & N/A \\
\hline $\begin{array}{l}\text { University of San } \\
\text { Diego }\end{array}$ & Yes & N/A \\
\hline $\begin{array}{l}\text { Valdosta State } \\
\text { University }\end{array}$ & No & $\begin{array}{l}\text { "all courses require a minimum of 2,250 engaged minutes per semester } \\
\text { hour." }\end{array}$ \\
\hline
\end{tabular}

\section{Exhibit C: Description of Credit Hour by Pedagogical Approach and University}

\begin{tabular}{|c|c|c|}
\hline University/System & Pedagogical Classifications & Example \\
\hline $\begin{array}{l}\text { East Carolina } \\
\text { University }\end{array}$ & $\begin{array}{l}\text { Clinical, Colloquia, } \\
\text { Individual Study, Internship, } \\
\text { Laboratory, Lecture, Physical } \\
\text { Activity, Practicum, } \\
\text { Recitation, Recital, Seminar, } \\
\text { Studio, Student Teaching, } \\
\text { Study Abroad, } \\
\text { Dissertation/Thesis }\end{array}$ & $\begin{array}{l}\text { Clinical: A course that requires medical- or healthcare- } \\
\text { focused experiential work where students test, observe, } \\
\text { experiment, or practice a field or discipline in a hands- } \\
\text { on or simulated environment. } \\
\text { Clinical experience credit hours are assigned based on } \\
40 \text { contact hours, or one week, per credit hour or } \\
\text { otherwise determined by programmatic accreditors. }\end{array}$ \\
\hline Alabama State & $\begin{array}{l}\text { Lecture, seminar, laboratory, } \\
\text { practice credit hour (clinical } \\
\text { rounds, visual or performing } \\
\text { art studio, student teaching, } \\
\text { field work), independent } \\
\text { study, internship }\end{array}$ & $\begin{array}{l}\text { One practice credit hour (supervised clinical rounds, } \\
\text { visual or performing art studio, supervised student } \\
\text { teaching, field work, etc.) represents } 3-4 \text { hours per } \\
\text { week of supervised and /or independent practice. This } \\
\text { in turn represents between } 45 \text { and } 60 \text { hours of work per } \\
\text { semester. Blocks of } 3 \text { practice credit hours, which } \\
\text { equate to a studio or practice course, represent between } \\
135 \text { and } 180 \text { total hours of academic work per semester. } \\
\text { There are some exceptions (e.g., teacher education } \\
\text { practica; College of Health Sciences clinical rounds and } \\
\text { labs). }\end{array}$ \\
\hline Iowa & $\begin{array}{l}\text { Face-to-face, laboratory, } \\
\text { hybrid/online }\end{array}$ & $\begin{array}{l}\text { One hour of credit may be awarded for laboratory and } \\
\text { discussion sections that meet a minimum of } 50 \text { minutes } \\
\text { per week and a maximum of } 150 \text { minutes per week. No } \\
\text { more than one credit may be awarded for lab and } \\
\text { discussion sections without approval of the College and } \\
\text { then of the Office of the Provost. } 1 \text { credit hour }=1 \text { to } 3 \\
\text { lab and discussion sessions ranging from a total of } 50 \text { to } \\
150 \text { minutes. }\end{array}$ \\
\hline $\begin{array}{l}\text { North Carolina } \\
\text { State }\end{array}$ & $\begin{array}{l}\text { Clinical, discussion, field } \\
\text { work, independent study, } \\
\text { internship, laboratory, lecture, } \\
\text { lecture \& lab, physical } \\
\text { activity, practicum, problem } \\
\text { session, recital/ } \\
\text { performance/ensemble, } \\
\text { recitation, research, seminar, } \\
\text { studio, student teaching }\end{array}$ & $\begin{array}{l}\text { Practicum: A course requiring students to participate in } \\
\text { an approved project or proposal that practically applies } \\
\text { previously studied theory of the field or discipline } \\
\text { under the supervision of an expert or qualified } \\
\text { representative of the field or discipline. Contact/Credit } \\
\text { Hour Ratio: } 10 \text { Contact Hours }(1 / 4 \text { time })=3 \text { Credit } \\
\text { Hours; } 20 \text { Contact Hours }(1 / 2 \text { time })=6 \text { Credit Hours; } \\
30 \text { Contact Hours }(3 / 4 \text { time })=9 \text { Credit Hours; } 40 \\
\text { Contact Hours (Full-time })=12 \text { Credit Hours }\end{array}$ \\
\hline
\end{tabular}




\begin{tabular}{|c|c|c|}
\hline $\begin{array}{l}\text { Ohio Department } \\
\text { of Higher } \\
\text { Education }\end{array}$ & N/A & $\begin{array}{l}\text { Credit hours may be calculated differently for the } \\
\text { following types of instructional activities: Laboratory } \\
\text { Instruction, practice experience, practicum, field } \\
\text { experience, observation, seminar, misc., studio } \\
\text { experience. }\end{array}$ \\
\hline Purdue & $\begin{array}{l}\text { Lecture, Recitation, } \\
\text { Laboratory, Lab Prep, Clinic, } \\
\text { Studio, Independent Study, } \\
\text { Distance, Non-directed study }\end{array}$ & $\begin{array}{l}\text { Laboratory - Normally, one credit hour is associated } \\
\text { with a class meeting for } 50 \text { to } 200 \text { minutes per week for } \\
\text { an entire semester (or the equivalent } 750 \text { to } 3,000 \\
\text { semester-minutes, excluding final exam, in other } \\
\text { meeting formats). Two semester credit hours could be } \\
\text { earned for a class meeting for } 150 \text { to } 300 \text { minutes per } \\
\text { week over the semester. (The overlap in minutes in } \\
\text { class allows for departmental discretion.) } \\
\text { Laboratory/Experiential Classes: A unit of credit } \\
\text { equates to } 3 \text { hours per week of direct instruction in a } \\
\text { laboratory/experiential setting, and } 1-3 \text { hours of out-of- } \\
\text { class student work per unit of credit. The latter range } \\
\text { allows for discipline and student level differentiation. } \\
\text { One quarter credit is assigned in the following ratio of } \\
\text { component hours per week devoted to the course of } \\
\text { study: (1) lecture \{and seminar\} courses-one contact } \\
\text { hour for each credit (two hours of outside work } \\
\text { implied); (2) laboratory, recitation, or studio courses--at } \\
\text { least two contact hours for each credit (one hour of } \\
\text { outside preparation implied); (3) independent study-at } \\
\text { least three hours of work per week for each credit." }\end{array}$ \\
\hline Samford & $\begin{array}{l}\text { Lecture/seminar, } \\
\text { Laboratory/experiential, } \\
\text { Studio, Ensemble/production, } \\
\text { Applied studio, clinical }\end{array}$ & $\begin{array}{l}\text { Laboratory/Experiential Classes (School of The Arts): } \\
\text { A unit of credit equates to } 4 \text { hours of student work per } \\
\text { week (1-3 hours in-class or direct instruction in a } \\
\text { laboratory/experiential setting plus a minimum of 1-3 } \\
\text { hours of out-of-class). The range allows for discipline } \\
\text { and student level differentiation. }\end{array}$ \\
\hline Oregon State & $\begin{array}{l}\text { Lecture, } \\
\text { laboratory/recitation/studio, } \\
\text { independent study }\end{array}$ & $\begin{array}{l}\text { One quarter credit is assigned in the following ratio of } \\
\text { component hours per week devoted to the course of } \\
\text { study: (1) lecture \{and seminar\} courses-one contact } \\
\text { hour for each credit (two hours of outside work } \\
\text { implied); (2) laboratory, recitation, or studio courses--at } \\
\text { least two contact hours for each credit (one hour of } \\
\text { outside preparation implied); (3) independent study-at } \\
\text { least three hours of work per week for each credit." }\end{array}$ \\
\hline $\begin{array}{l}\text { University of San } \\
\text { Diego }\end{array}$ & $\begin{array}{l}\text { Laboratory, Team-taught } \\
\text { honors, Internship, Studio, } \\
\text { Southeast San Diego Tutoring } \\
\text { Project, Clinical Nursing, } \\
\text { Independent Study, LLC } \\
\text { Scholastic, Practica, Online }\end{array}$ & $\begin{array}{l}\text { One unit of credit has been assigned to at least } 40 \text { hours } \\
\text { of internship work throughout the course of one } \\
\text { semester. (Source: anthropology ( } 3 \text { hours a week for } \\
\text { approximately } 13 \text { weeks) communication ( } 40 \text { ), history } \\
\text { ( } 3 \text { units is } 9 \text { hours per week for } 13.5 \text { weeks and } \\
\text { involves } 120 \text { hours of work) sociology ( } 40) \text {, math and } \\
\text { cs ( } 40 \text { ), psychology ( } 40 \text { ), MARS ( } 45 \text { ), SBA UG } 96 \text { for } \\
\text { 3-units plus } 3 \text { class meetings, SBA grad } 120 \text { units plus } \\
\text { two class meetings). }\end{array}$ \\
\hline
\end{tabular}




\section{Exhibit D: Final Examination Policy}

There will be no departure from the printed schedule, except as noted below: All examinations for one credit hour classes will be held during the last regular meeting of the class. Classes meeting more than three times a week will follow the examination schedule for MWF classes. Clinical and nontraditional class schedules, including graduate level courses, may also adopt a modified examination schedule as required. The final exam meeting is required in order to satisfy the $\mathbf{7 5 0}$ contact minutes per credit hour required by the University of North Carolina Office of the President. Department Chairs are responsible for monitoring adherence to scheduled examination requirements. 